https://doi.org/10.15407/dopovidi2021.05.061

UDC 550.4 (477); 551.21:551.24

G.V. Artemenko ${ }^{1}$, https://orcid.org/0000-0002-4528-6853

L.V. Shumlyanskyy ${ }^{1,2}$, https://orcid.org/0000-0002-6775-44199

${ }^{1}$ M.P. Semenenko Institute of Geochemistry, Mineralogy and Ore Formation of the NAS of Ukraine, Kyiv

${ }^{2}$ Curtin University, School of Earth and Planetary Sciences, Perth, Australia

E-mail: regulgeo@gmail.com, leonid.shumlyanskyy@curtin.edu.au

\title{
The Paleoarchean and Mesoarchean TTGs of the western Azov area, the Ukrainian Shield
}

Presented by Academician of the NAS of Ukraine O.M. Ponomarenko

A large anticline structure occurs in the western part of the Azov Domain of the Ukrainian Shield. It is composed of rocks of the Mesoarchean (3.2-3.0 Ga) granite-greenstone association and relics of an older basement. The anticline is divided into two parts by the Bilotserkivka structure of sub-latitudinal strike. The northern part includes the Huliaipole and Remivka blocks, and the southern part comprises the Saltycha anticline. The U-Pb age of plagiogneisses of the Lantsevo anticline of the Bilotserkivka structure is $3299 \pm 11 \mathrm{Ma}$. In terms of geochemical characteristics, they correspond to TTGs. In the western part of the Bilotserkivka structure, we previously identified quartz diorites having an age of $3297 \pm 22 \mathrm{Ma}$. These data show that the Bilotserkivka structure represents an ancient basement. Dislocated trondhjemites were studied in the Ivanivka area at the eastern part of the Saltycha anticline. They contain numerous relics of heavily altered amphibolites. The U-Pb age of zircons from trondhjemite is $3013 \pm 15 \mathrm{Ma}$. These rocks are of the same age as TTGs of the Shevchenko Complex cutting through the sedimentary-volcanogenic rocks of the greenstone structures of the Azov Domain. They share age and geochemical characteristics with biotite and amphibole-biotite gneisses of the "Kainkulak beds" in the Zrazkove village located at the Mokra Konka river (3.1-3.0 Ga) and with biotite gneisses in the lower reaches of the Kainkulak river (2.92 Ga). Thus, gneisses of the "Kainkulak beds" actually represent the Mesoarchean TTGs of the Shevchenko Complex, transformed in the Paleoproterozoic time due to the dislocation metamorphism. The late Paleoarchean (3.3 Ga) tonalites are known in the West Azov and KMA domains; they probably also occur in the basement of the Middle Dnieper domains, where detrital zircons of this age have been reported. These data allow us to assume the existence of a large Late Paleoarchean (3.3 Ga) protocraton, in which the Mesoarchean (3.2-3.0 Ga) greenstone belts and TTGs of the eastern part of the Ukrainian Shield and the KMA Domain were formed.

Keywords: West Azov, Bilotserkivka structure, Paleoarchean protocraton, Mesoarchean craton, TTG, Ukrainian Shield, zircon, $U-P b$ age.

Ци ту в ання: Artemenko G.V., Shumlyanskyy L.V. The Paleoarchean and Mesoarchean TTGs of the western Azov area, the Ukrainian Shield. Допов. Нац. акад. наук Укр. 2021. № 5. С. 61-74.

https://doi.org/10.15407/dopovidi2021.05.061

ISSN 1025-6415. Допов. Наи. акад. наук Укр. 2021. № 5: 61-74 
Introduction. A large anticline structure that comprises the West Azov and Remivka blocks occurs in the western part of the Azov Domain of the Ukrainian Shield. These blocks are composed of rocks of the Mesoarchean $(3.2-3.0 \mathrm{Ga}$ ) granite-greenstone association and relics of an older basement. The anticline is divided into two parts by the Bilotserkivka structure of sub-latitudinal strike; the northern part includes the Huliaipole and Remivka blocks, and the southern part is comprised of the Saltycha anticline (Fig. 1). The Archean plagiogranitoids of the West Azov underwent the intense dislocation metamorphism during the Paleoproterozoic. In many areas, they were transformed into plagioclase gneisses that were attributed to the Paleoarchean "Kainkulak beds" of the West Azov Series [1]. Alternating thin "layers" of biotite-, amphibole-, and biotite-amphibole gneisses crop out locally in the upper reaches of the Konka and Kainkulak rivers. A high degree of dislocation metamorphism is observed in plagiogranitoids of the peripheral parts of the Saltycha anticline. Archean rocks are strongly deformed in the Bilotserkivka structure, where plagiogneisses with a thin-stripe structure can be observed. For this reason, detailed geological-structural and geochronological studies are required for the chronostratigraphic subdivision of these gneisses. We have chosen two areas for our studies: the Lantsevo anticline within the Bilotserkivka structure and the Ivanivka area in the eastern part of the Saltycha anticline (see Fig. 1).

Geological structure of the studied areas. The Bilotserkivka structure (up to $20 \times 45 \mathrm{~km}$ in size) of a sub-latitudinal strike is located between the Haichur block and Saltycha anticline (see Fig. 1). In the east, it borders the Central Azov syncline, and its western boundary is drawn along the Chernihivka fault [3]. The inclination of the rocks of the Bilotserkivka structure along the contacts in the west, north, and south is very steep, ranging from $70-80^{\circ}$ to $90^{\circ}$. Several anticline and syncline folds are found within its borders. The synclines are composed of rocks of the Dragunove beds (formerly known as the Temryuk Suite of the Central Azov Series),
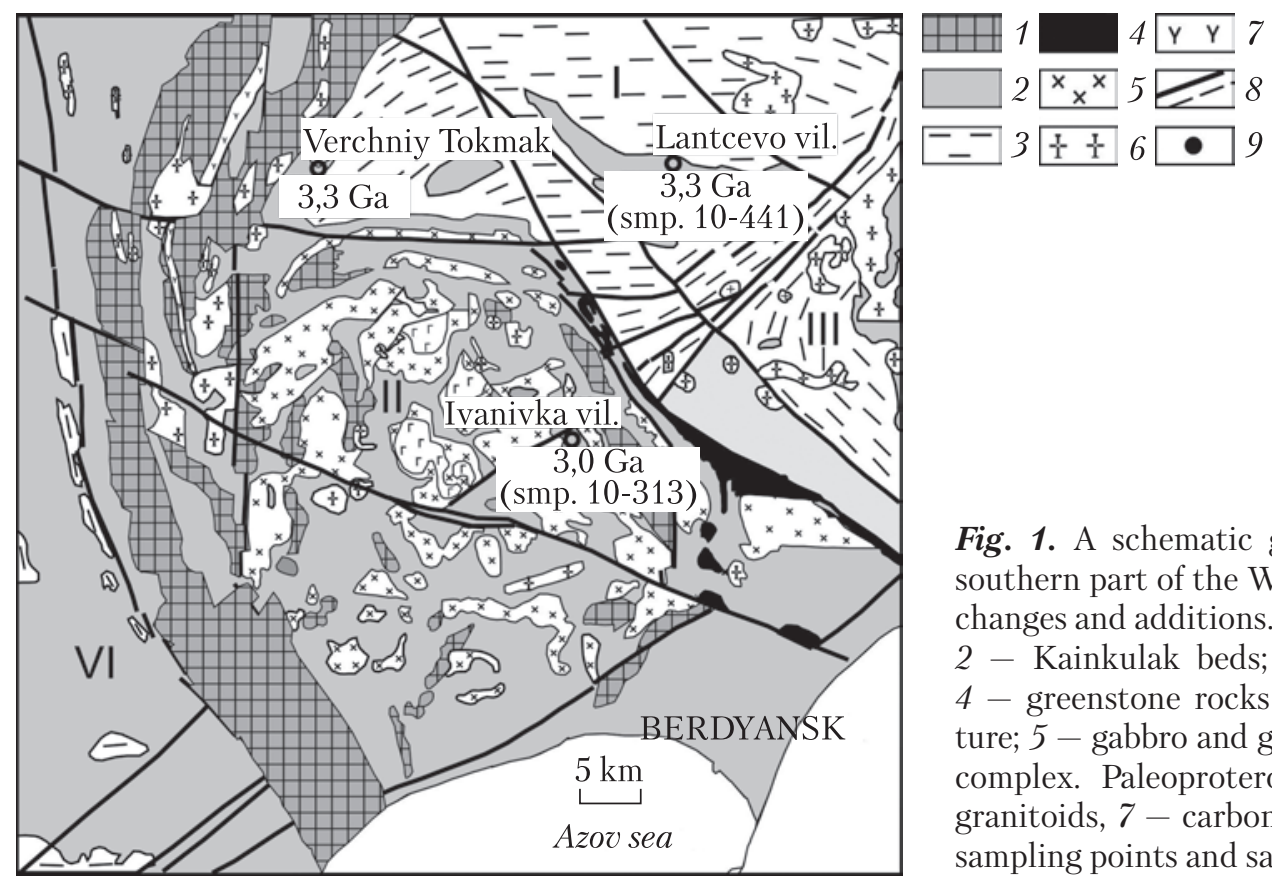
whereas anticlines (Oleksiivo, Lantsevo, etc.) are composed of plagiogneisses of the "Kainkulak beds" with relics of two-pyroxene crystalline schists, amphibolites, and ferruginous-siliceous rocks [2,4]. Metamorphic rocks compose lenses and slices from a few centimeters to hundreds of meters thick.

The Saltycha anticline is a dome-shaped structure having an area of about $2000 \mathrm{~km}^{2}$. Its prevalent area is composed of plagiogranitoids (TTGs) of the Shevchenko Complex and gneisses of the West Azov Series. Among them, relics of amphibolites and meta-ultrabasic rocks having a thickness of up to $400 \mathrm{~m}$, are found. More than half of the area of the Saltycha anticline is occupied by small (up to $85 \mathrm{~km}^{2}$ ) intrusions of gabbro, diorites, and granodiorites of the Obitochne complex having an age of 2.91-2.92 Ga. Their geochemical characteristics correspond to intraplate magmatic rocks [5]. Paleoproterozoic potassium-sodium granitoids of the Saltycha and Anadol complexes are spread in a part of the Saltycha anticline. They compose small stocks having an area of up to $2.5 \mathrm{~km}^{2}$, as well as smaller bodies confined mainly to tectonic zones.

Analytical methods. Zircon has been extracted from the rock using a shaking table, heavy liquids, and a magnetic separator to produce a heavy non-magnetic fraction. Zircons were handpicked under a binocular microscope. Zircon morphology has been studied under an optical microscope, whereas the internal structure was documented using cathodoluminescence. U-Pb isotopic data were collected using the laser ablation inductively coupled plasma mass spectrometry (LA-ICP-MS) in the GeoHistory Facility, John de Laeter Centre, Curtin University. Zircon was ablated using a Resonetics RESOlution M-50A-LR system, incorporating a COMPex 102-193 nm excimer UV laser that was coupled to an Agilent 8900 QQQ mass spectrometer. Zircon standard OG1 (3465 $\pm 0.6 \mathrm{Ma}[6]$; all uncertainties at $2 \sigma$ ) was utilized as the primary reference material and analyzed in blocks with secondary standards GJ-1 (601.2 $\pm 0.4 \mathrm{Ma}$ [7]), and Plešovice (337.13 $\pm 0.37 \mathrm{Ma}[8])$. The secondary standards yielded weighted mean ${ }^{207} \mathrm{~Pb} /{ }^{206} \mathrm{~Pb}$ ages and ${ }^{238} \mathrm{U} /{ }^{206} \mathrm{~Pb}$ ages within an uncertainty of the recommended values. The time-resolved mass spectra were reduced using Iolite $3.7^{\mathrm{TM}}$ ([9] and references therein) with final ages calculated using Isoplot. Silicate rock analyses were carried out at IGMOF of the NAS of Ukraine, Kyiv.

Research results. The Bilotserkivka structure (area of the Lantsevo village). We have dated plagiogneisses of the Lantsevo anticline that were considered to belong to the Kainkulak beds [2]. They often host large xenoliths of metamorphic rocks, i.e., two-pyroxene and pyroxene schists and pyroxene-magnetite quartzites. A sample of biotite gneisses was taken in the upper reaches of the Berda river right tributary (ravine), at the north-eastern outskirts of the Lantsevo village. Bedding elements of gneisses: strike NW $275^{\circ}$, dip NE $5^{\circ}$, inclination $65^{\circ}$.

Biotite gneiss (sample 10-441) has a lepidogranoblastic texture and the following mineral composition (vol. \%): feldspar (albite) - 75; quartz - 15; biotite $-5-7$; clinopyroxene $-1-2$; apatite, zircon - single grains. In terms of the chemical composition [7], biotite gneiss belongs to the family of granodiorite-tonalites of the potassium-sodium series $\left(\mathrm{SiO}_{2}=65.05 \% ; \mathrm{Al}_{2} \mathrm{O}_{3}=\right.$ $=14.79 \% ; \mathrm{Na}_{2} \mathrm{O}=4.40 \% ; \mathrm{K}_{2} \mathrm{O}=1.16 \%$ ) (Table 1$)$. These rocks have low $\mathrm{Mg} \#=33.9$. In the O'Connor-Barker classification diagram Ab-An-Or, they plot in the tonalite field. They are poor in $\mathrm{Rb}(25.7 \mathrm{ppm})$ and rich in $\mathrm{Sr}(313 \mathrm{ppm})$ (Table 2). Average concentrations of HFS elements are as follows: $\mathrm{Y}(7.4 \mathrm{ppm}), \mathrm{Nb}(6.5 \mathrm{ppm}), \mathrm{Yb}(0.75 \mathrm{ppm})$; an average concentration of Ni (the only transition element found) is $19.7 \mathrm{ppm}$. The multielement diagram shows 


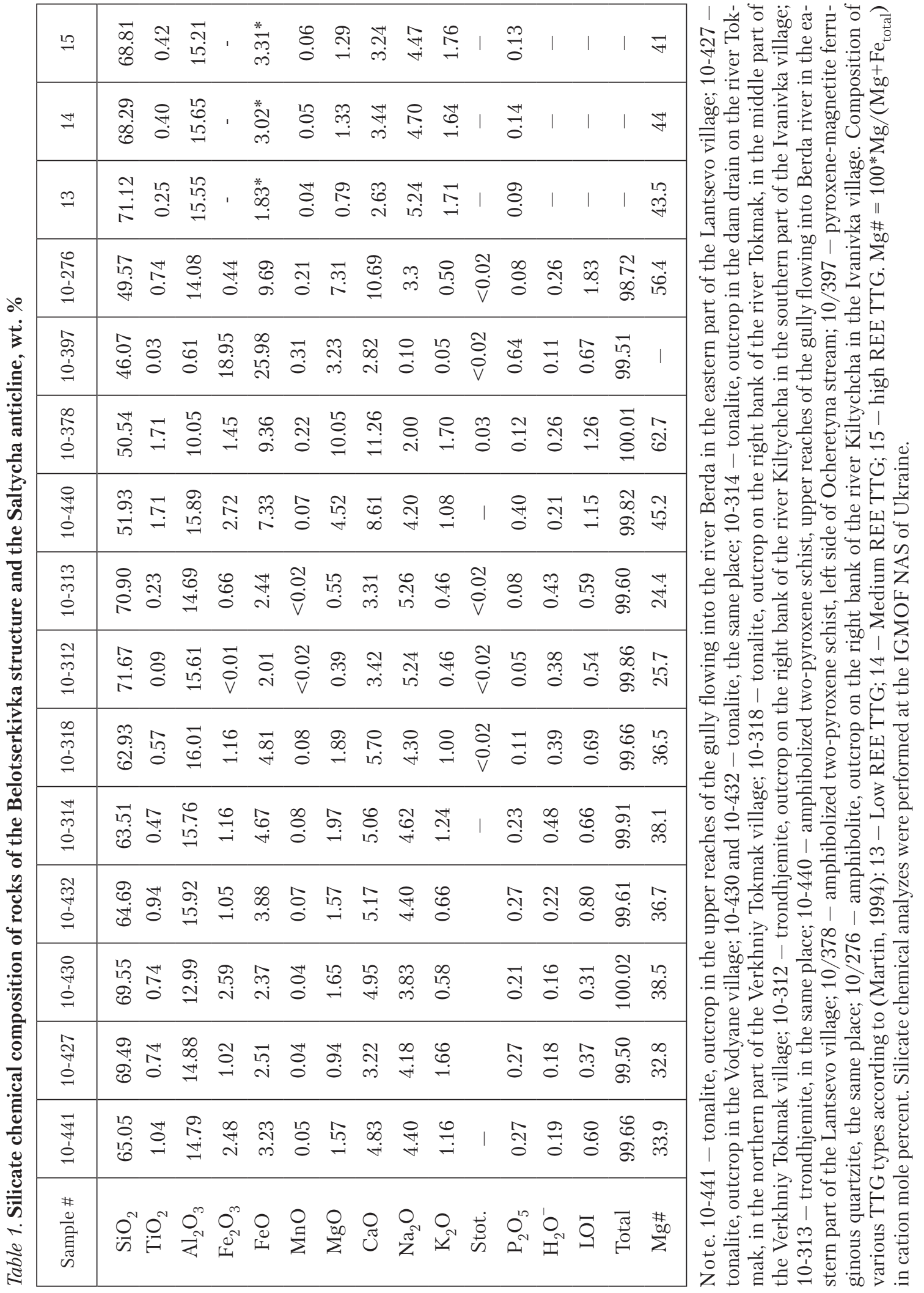



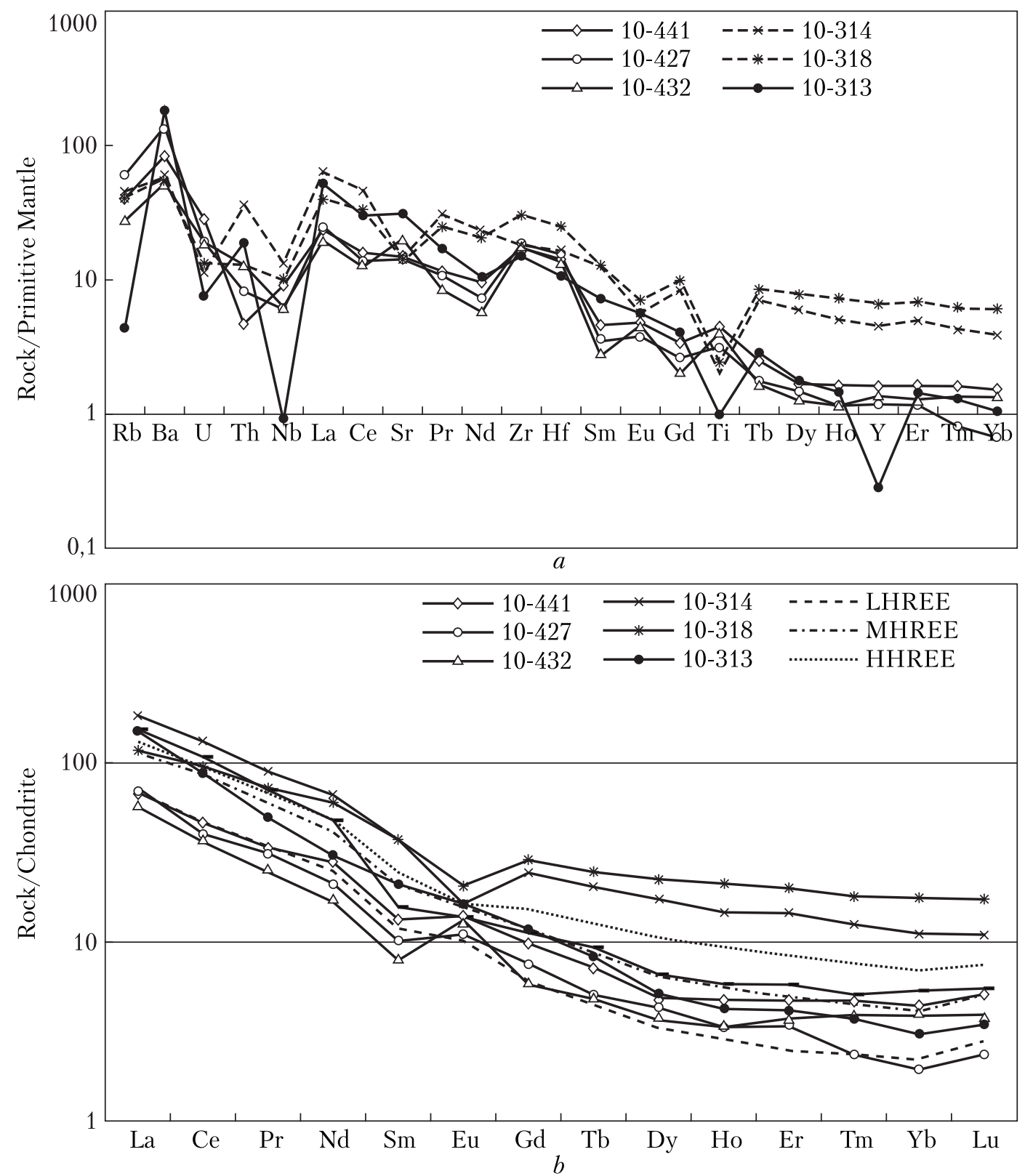

Fig. 2. $a$ : Multielement diagrams for tonalites of the Bilotserkivka structure and trondhjemites of the Saltycha anticline. Normalized to the primitive mantle [10].

$b$ : REE distribution for tonalites of the Bilotserkivka structure and trondhjemites of the Saltycha anticline. Normalized to the composition of chondrite [10]

positive $\mathrm{Ti}, \mathrm{Eu}$, and $\mathrm{Sr}$ anomalies, and negative $\mathrm{Nb}$ anomaly (Fig. 2, a). The REE pattern is differentiated: $(\mathrm{La} / \mathrm{Yb})_{\mathrm{N}}=15.5$ at $\mathrm{Yb}_{\mathrm{N}}=4.4$ (Fig. 2, b). A positive europium anomaly is found: $\mathrm{Eu} / \mathrm{Eu}^{*}=1.2$.

The Saltycha anticline. Separate outcrops of trondhjemites with numerous metabasite relics are observed in a one-kilometer-long section on the right steep bank of the Kiltichia river in the Ivanivka village. Amphibolites are cut by trondhjemite veins. In the southern part of this section, 
Table 2. Trace elements concentrations in rocks of the Belotserkivka structure and Saltycha anticline

\begin{tabular}{|c|c|c|c|c|c|c|c|c|c|c|c|c|}
\hline Ppm & $10-441$ & $10-427$ & $10-432$ & $10-314$ & $10-318$ & $10-313$ & $10-378$ & $10-397$ & $10-276$ & $\begin{array}{l}\text { Low } \\
\text { REE }\end{array}$ & $\begin{array}{l}\text { Med } \\
\text { REE }\end{array}$ & $\begin{array}{l}\text { High } \\
\text { REE }\end{array}$ \\
\hline $\mathrm{Rb}$ & 25.7 & 38.3 & 17.5 & 29.0 & 25.9 & 2.8 & 2.9 & 3.3 & 0.5 & 46.4 & 55.0 & 70.6 \\
\hline $\mathrm{Sr}$ & 313 & 30 & 426 & 315 & 299 & 657 & 290 & 153 & 24.9 & 583 & 483 & 327 \\
\hline $\mathrm{Ba}$ & 583 & 966 & 367 & 417 & 390 & 1279 & 391 & 162 & 9.8 & 542 & 531 & 447 \\
\hline $\mathrm{V}$ & 76 & 29 & 82 & 75 & 65 & 29 & 283 & 234 & 13 & 213 & 36 & 42 \\
\hline $\mathrm{Cr}$ & 50 & 30 & 50 & 21.3 & 14.6 & 15.5 & 103 & 749 & 22.8 & 42.5 & 38.2 & 27.6 \\
\hline Co & 13.6 & 6.3 & 13.7 & 15.9 & 15.1 & 5.5 & 49.10 & 56.61 & 3.32 & - & - & - \\
\hline $\mathrm{Ni}$ & 19.7 & 13.1 & 18.9 & 29.0 & 31.7 & 12.8 & 138 & 239 & 13.9 & 86.2 & 21.6 & 15.2 \\
\hline $\mathrm{Cu}$ & 31.3 & 12.0 & 37.8 & 36.1 & 45.9 & 37.4 & 47.0 & 29.82 & 6.95 & - & - & - \\
\hline $\mathrm{Zn}$ & 45 & 44 & 30 & 83 & 69 & 27 & 117 & 107 & 18 & - & - & - \\
\hline $\mathrm{Ga}$ & 15.7 & 15.4 & 15.8 & 19.5 & - & 16.1 & 16.7 & 16.8 & 1.9 & - & - & - \\
\hline Y & 7.4 & 5.4 & 6.2 & 20.7 & 30.0 & 1.3 & 16.0 & 14.4 & 8.4 & 5.4 & 8.3 & 18.2 \\
\hline $\mathrm{Nb}$ & 6.5 & 4.3 & 4.5 & 9.5 & 7.1 & 0.6 & 2.5 & 3.1 & 2.4 & 2.9 & 5.3 & 8.1 \\
\hline $\mathrm{Ta}$ & 2.0 & 0.4 & 1.2 & 0.56 & 0.24 & 0.02 & - & - & - & 0.52 & 0.81 & 0.79 \\
\hline $\mathrm{Zr}$ & 193 & 208 & 195 & 199 & 343 & 168 & 41 & 42 & 2.6 & 114 & 143 & 174 \\
\hline Hf & 4.4 & 4.8 & 4.2 & 5.1 & 7.7 & 3.3 & 1.1 & 1.4 & 0.1 & 3.0 & 4.2 & 4.5 \\
\hline U & 0.60 & 0.40 & 0.40 & 0.24 & 0.28 & 0.16 & 4.50 & 0.11 & 0.18 & 0.83 & 1.31 & 1.83 \\
\hline $\mathrm{Th}$ & 0.40 & 0.70 & 1.10 & 3.10 & 1.10 & 1.60 & 0.66 & 0.63 & 0.27 & 3.86 & 6.16 & 7.16 \\
\hline $\mathrm{La}$ & 16.2 & 17.2 & 13.5 & 43.7 & 27.8 & 35.7 & 4.7 & 9.0 & 3.4 & 16.4 & 26.9 & 31.0 \\
\hline $\mathrm{Ce}$ & 28.3 & 24.6 & 22.2 & 80.8 & 58.7 & 53.6 & 12.4 & 20.96 & 8.03 & 28.72 & 52.87 & 57.91 \\
\hline $\operatorname{Pr}$ & 3.21 & 2.98 & 2.33 & 8.5 & 6.90 & 4.70 & 1.80 & 2.70 & 1.03 & - & - & - \\
\hline $\mathrm{Nd}$ & 13.0 & 9.9 & 7.8 & 30.9 & 28.0 & 14.2 & 7.7 & 12.1 & 4.8 & 11.6 & 19.3 & 22.5 \\
\hline $\mathrm{Sm}$ & 2.05 & 1.55 & 1.21 & 5.70 & 5.70 & 3.22 & 2.20 & 2.94 & 1.19 & 1.82 & 3.18 & 3.76 \\
\hline $\mathrm{Eu}$ & 0.81 & 0.64 & 0.77 & 0.95 & 1.20 & 0.95 & 0.67 & 0.97 & 0.60 & 0.59 & 0.91 & 0.95 \\
\hline $\mathrm{Gd}$ & 2.02 & 1.56 & 1.19 & 5.00 & 5.90 & 2.43 & 2.40 & 3.37 & 1.46 & 1.24 & 2.43 & 3.15 \\
\hline $\mathrm{Tb}$ & 0.27 & 0.19 & 0.18 & 0.76 & 0.92 & 0.31 & 0.41 & 0.54 & 0.24 & - & - & - \\
\hline Dy & 1.24 & 1.09 & 0.93 & 4.40 & 5.70 & 1.31 & 2.80 & 3.50 & 1.68 & 0.84 & 1.63 & 2.68 \\
\hline Но & 0.27 & 0.19 & 0.19 & 0.83 & 1.20 & 0.24 & 0.66 & 0.68 & 0.35 & - & - & - \\
\hline Er & 0.78 & 0.56 & 0.62 & 2.40 & 3.30 & 0.69 & 2.10 & 1.99 & 1.10 & 0.41 & 0.81 & 1.39 \\
\hline $\mathrm{Tm}$ & 0.12 & 0.06 & 0.10 & 0.32 & 0.46 & 0.10 & 0.31 & 0.27 & 0.16 & - & - & - \\
\hline $\mathrm{Yb}$ & 0.75 & 0.33 & 0.66 & 1.90 & 3.00 & 0.52 & 2.10 & 1.74 & 1.07 & 0.38 & 0.70 & 1.18 \\
\hline $\mathrm{Lu}$ & 0.13 & 0.06 & 0.10 & 0.28 & 0.44 & 0.09 & 0.30 & 0.25 & 0.16 & 0.07 & 0.13 & 0.19 \\
\hline Mo & 0.5 & 0.5 & 0.4 & 0.5 & 0.8 & $<1$ & 0.3 & 0.5 & 1.3 & - & - & - \\
\hline $\mathrm{Pb}$ & 1.1 & 1.0 & 1.2 & 9.4 & 10.4 & 7.83 & 5.70 & 2.89 & 0.63 & - & - & - \\
\hline $\mathrm{Yb}_{\mathrm{N}}$ & 4.4 & 1.9 & 3.9 & 11.2 & 17.6 & 3.1 & 12.4 & 10.2 & 6.3 & 2.2 & 4.1 & 6.9 \\
\hline$(\mathrm{La} / \mathrm{Yb})_{\mathrm{N}}$ & 15.5 & 37.4 & 14.7 & 16.5 & 6.7 & 49.2 & 3.7 & 2.3 & 1.6 & 28.7 & 26.0 & 17.7 \\
\hline $\mathrm{Eu} / \mathrm{Eu}^{*}$ & 1.2 & 1.3 & 2.0 & 0.5 & 0.6 & 1.0 & 0.9 & 0.9 & 1.4 & 1.2 & 1.0 & 0.8 \\
\hline $\mathrm{Sr} / \mathrm{Y}$ & 42.3 & 55.5 & 68.7 & 15.2 & 10.0 & 80.3 & 18.1 & 10.6 & 3.0 & 107.2 & 58.1 & 18.0 \\
\hline $\mathrm{Nb} / \mathrm{Ta}$ & 3.3 & 10.8 & 3.8 & 17 & 29.6 & 33.6 & - & - & - & 5.6 & 6.5 & 10.3 \\
\hline
\end{tabular}

Note. For the description of samples see Table 1. 
amphibolites strike NW $300^{\circ}$, dip NE $30^{\circ}$, inclination $75^{\circ}$; at the northern edge, their strike is changed to a latitudinal one.

A sample of trondhjemites (10-313) was taken in the area located ca. $500 \mathrm{~m}$ away from the southern outskirts of the Ivanivka village. The rock is fine-grained, the texture is lepidogranoblastic. Mineral composition (vol. \%): plagioclase (albite) - 65; quartz - 25; biotite $-5-7$; K-feldspar $-2-3$; single grains of apatite, zircon, and opaque minerals. Feldspar is replaced by accumulations of secondary minerals.

In terms of the chemical composition [11], trondhjemites correspond to low alkaline granites $\left(\mathrm{SiO}_{2}=70.90-71.67 ; \mathrm{Al}_{2} \mathrm{O}_{3}=14.69-15.61 \% ; \mathrm{Na}_{2} \mathrm{O}=5.24-5.26 \% ; \mathrm{K}_{2} \mathrm{O}=0.46 \%\right)$ of the sodium series (see Table 1). The $\mathrm{Mg} \#$ of the rock is low (25.7-36.2). In the O'Connor-Barker diagram, they plot in the trondhjemite field. They are poor in $\mathrm{Rb}(2.8)$ and rich in $\mathrm{Sr}$ (657 ppm) (see Table 2). They also have a very low content of such HFSE as Y (1.3 ppm), Nb (0.6 ppm), Yb (0.5 ppm), and of transitional elements, namely, Ni (12.8 ppm) and $\mathrm{Cr}(15.5 \mathrm{ppm})$. Negative anomalies of $\mathrm{Nb}$ and $\mathrm{Ti}$ and positive anomalies of $\mathrm{Sr}$ and $\mathrm{Eu}$ (see Fig. 2, a) are seen in the multielement diagram. The REE pattern is highly differentiated: $(\mathrm{La} / \mathrm{Yb})_{\mathrm{N}}=49.2, \mathrm{Yb}_{\mathrm{N}}=3.1($ see Fig. 2, $b$ ). In terms of their geochemical characteristics, trondhjemites correspond to TTGs [12].

Numerous amphibolite xenoliths of a uniform composition, a few meters in size, are found in trondhjemites in the Ivanivka area. In terms of the chemical composition, these are mafic rocks of the normal sodium series $\left(\mathrm{SiO}_{2}=49.57 \% ; \mathrm{TiO}_{2}=0.74 \% ; \mathrm{MgO}=7.31 \% ; \mathrm{Na}_{2} \mathrm{O}=3.3 \% ; \mathrm{K}_{2} \mathrm{O}=\right.$ $0.50 \%$ ) (see Table 1). They are low in $\mathrm{Ti}$ and have a low $\mathrm{Mg} \#=42$. In terms of geochemical characteristics, they are similar to THI tholeiitic basalts.

Results of the U-Pb zircon dating. We have analyzed 32 zircon grains in sample 10-441. In six grains, two analyses were performed, one in the core part of the crystal, and another one in the marginal part (Fig. 3,a). Altogether, 38 analyses were carried out in this sample. The results of these analyses are reported in Table 3.

In general, the obtained results spread along the discordia line that intercepts the concordia at $3374 \pm 61$ and $2530 \pm 240 \mathrm{Ma}$ (see Fig. 3, b). However, most of the results (22 spots) cluster near the upper intercept; the concordia age calculated for this cluster is $3299 \pm 11 \mathrm{Ma}$ (see Fig. 3, c). We accept that age as the time of the primary tonalite crystallization. The lower intercept age may indicate a metamorphic event during which primary igneous tonalite was transformed into biotite gneiss. In the cases where zircon grains were analyzed in two spots, the core portions have yielded lower ages than the margins. This may be explained by variable Pb-loss during the metamorphic event rather than by the presence of younger zircon populations in the sample.

Sample 10-313. In total, 52 analyses have been performed in 42 grains separated from trondhjemite of the Saltycha anticline (Ivanivka village). Ten grains were analyzed both in the core and marginal parts of the crystals (Fig. 4, $a$ ). Results of the analyses are reported in Table 3.

Around $65 \%$ of the analyses yielded concordant results, while the rest demonstrate a significant spread toward younger ages. The upper intercept age calculated for all results is $3027 \pm$ $\pm 30 \mathrm{Ma}$ (the low intercept is at ca. $500 \mathrm{Ma}, \mathrm{MSWD}=12$ ) (see Fig. 4, $b$ ). The weighted average ${ }^{207} \mathrm{~Pb} /{ }^{206} \mathrm{~Pb}$ age calculated for the concordant results is $3013 \pm 15 \mathrm{Ma}(\mathrm{MSWD}=3.9$ ). We assume that this age corresponds to the time of the initial trondhjemite crystallization.

Discussion and conclusions. The Paleoarchean (ca. 3.3 Ga) age of tonalites of the Lantsevo anticline in the Bilotserkivka structure has been established. A similar age was earlier obtained 

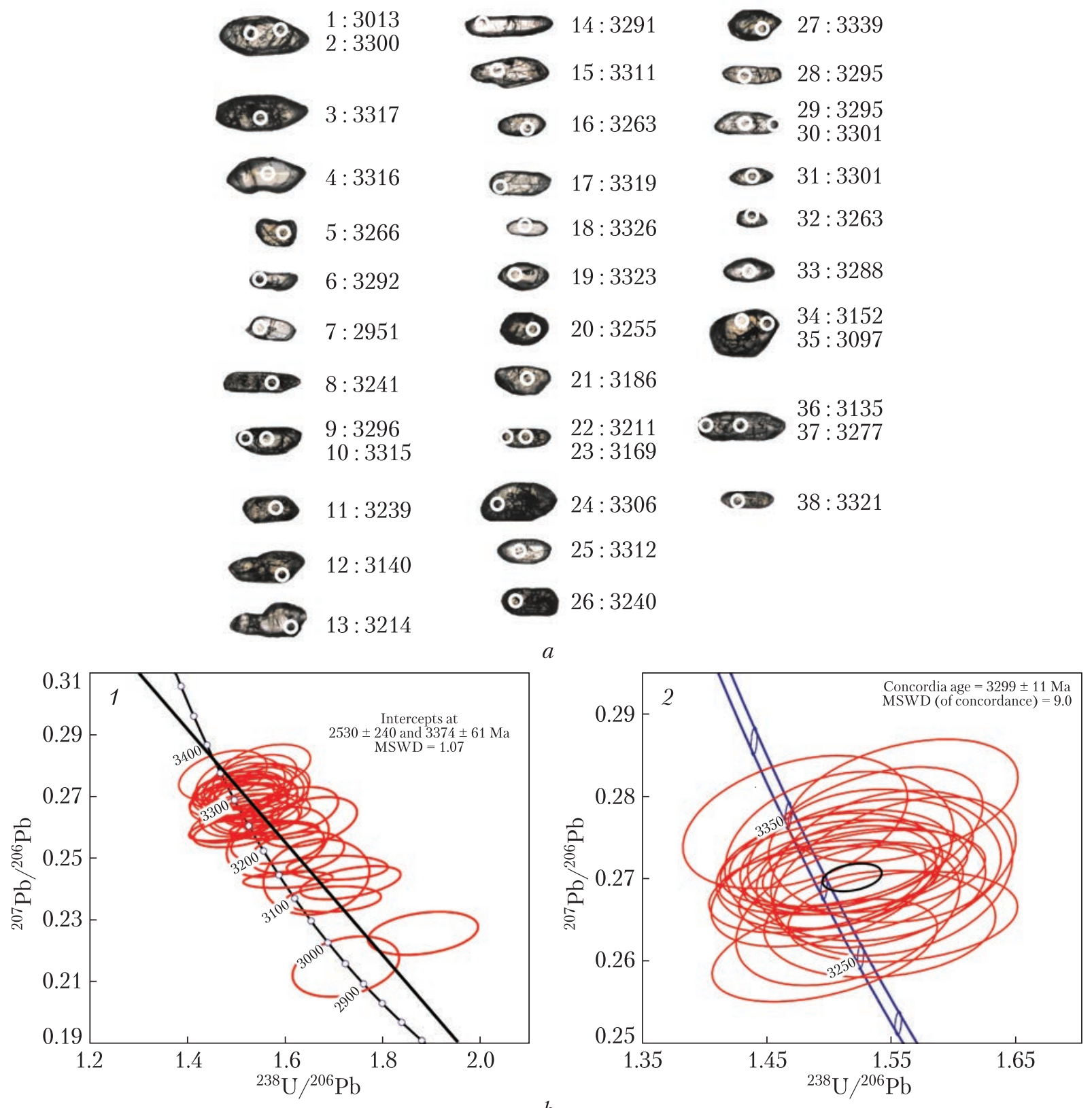

Fig. 3. $a$ : Optical images of the studied zircon crystals from biotite gneisses of the Lantsevo anticline of the Bilotserkivka structure (sample 10-441). Numbers of the analyses and their ${ }^{207} \mathrm{~Pb} /{ }^{206} \mathrm{~Pb}$ ages as in Table 3 .

$b$ : U-Pb diagram for zircons from biotite gneisses of the Lantsevo anticline of the Bilotserkivka structure (sample 10-441). 1 - diagram showing all results and corresponding concordia intercepts; 2 - the concordia age for the ca. 3000 Ma cluster

for tonalites located at $30 \mathrm{~km}$ in the western part of the Bilotserkivka structure (Verkhniy Tokmak area) [13]. Tonalites of the Lantsevo anticline have been formed under a medium pressure according to [12]. They have low concentrations of heavy REE and a positive anomaly Eu/Eu* $=$ $=1.2$. Rare earth elements are highly differentiated $(\mathrm{La} / \mathrm{Yb})_{\mathrm{N}}=14.7-37.4 ; \mathrm{Nb} / \mathrm{Ta}$ ratio varies 


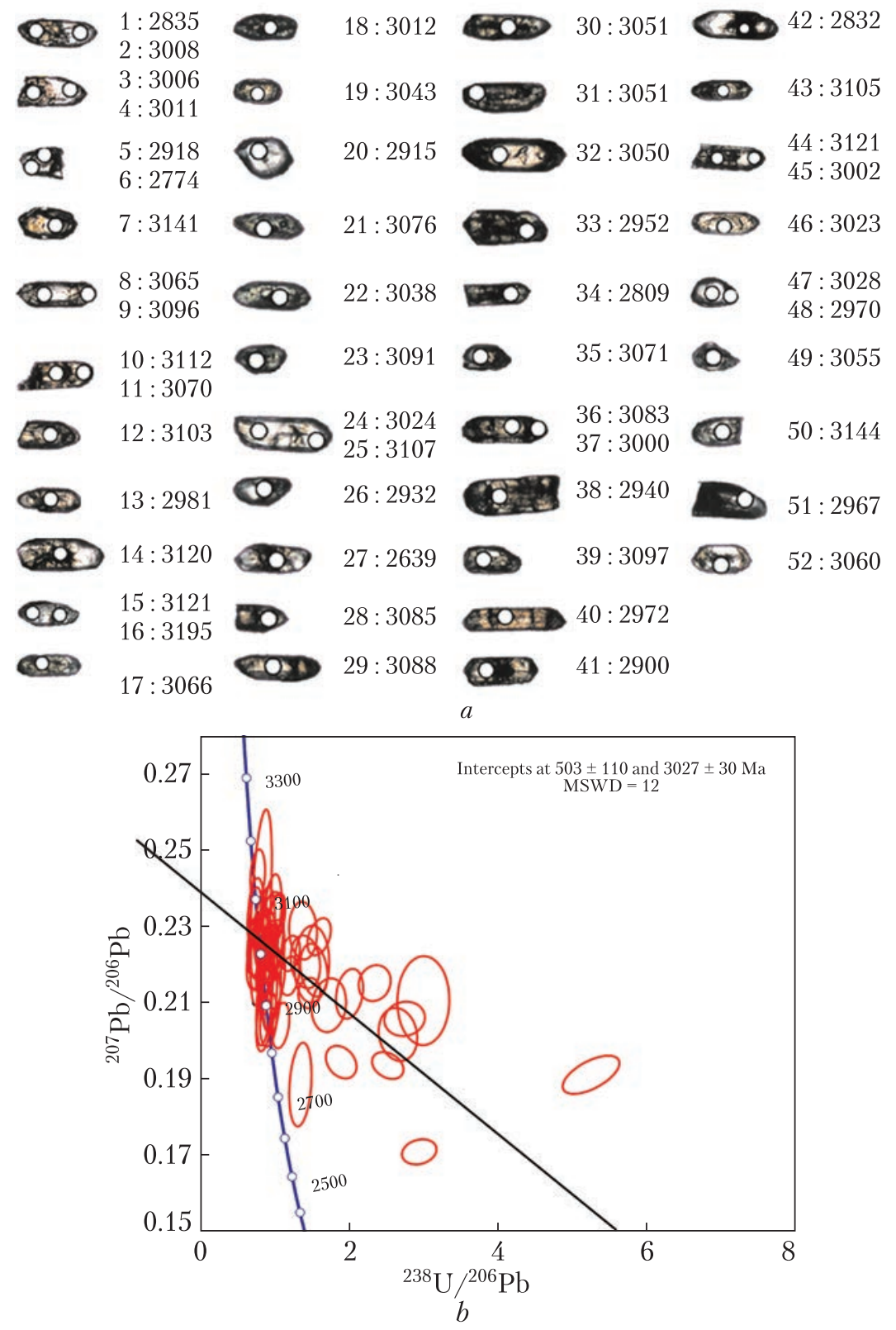

Fig. 4. $a$ : Optical images of the studied zircon crystals from trondhjemite of the Saltycha anticline (sample 10-313). Numbers of the analyses and ${ }^{207} \mathrm{~Pb} /{ }^{206} \mathrm{~Pb}$ ages as in Table 3.

$b$ : U-Pb diagram with concordia for zircon from trondhjemite (Saltycha anticline, Ivanivka village, sample 10-313)

from 3.3 to 10.8. In contrast, tonalites of the Verhniy Tokmak area belong to the low-pressure TTG according to [12]. They have high concentrations of heavy REE and the negative anomaly $\mathrm{Eu} / \mathrm{Eu}^{*}=0.54-0.63$. Rare earth elements are highly differentiated $-(\mathrm{La} / \mathrm{Yb})_{\mathrm{N}}=6.65-16.50$; $\mathrm{Nb} / \mathrm{Ta}$ ratio varies from 17 to 29.6 .

Paleoarchean tonalites of the Lantsevo anticline contain remnants of supracrustal rocks metamorphosed in the granulite facies (two-pyroxene schists, pyroxene-magnetite quartzites, and gar- 


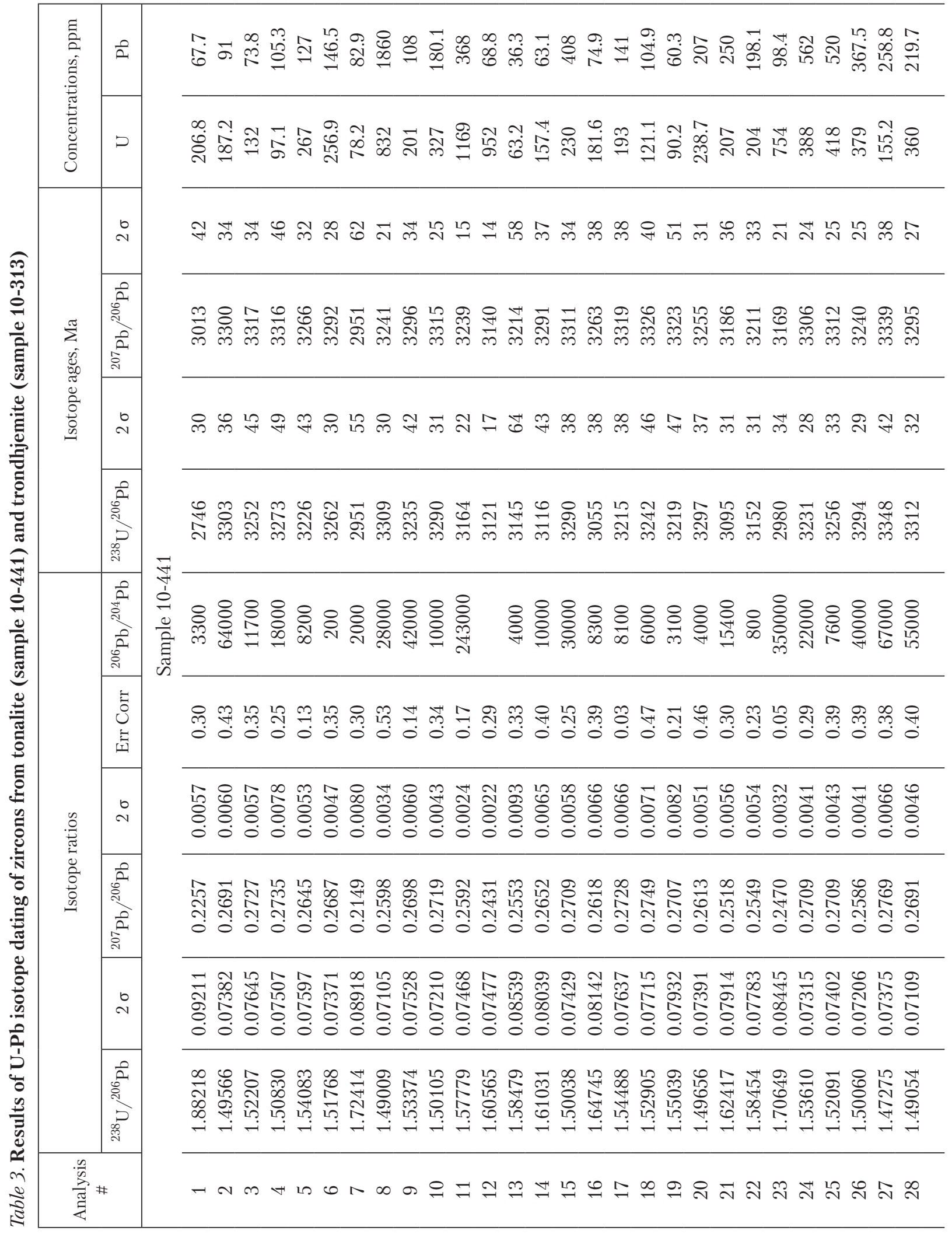




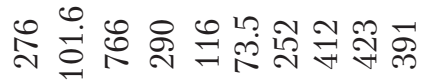

๙ิ

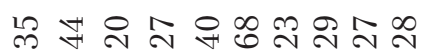

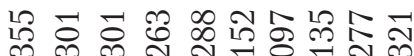
m

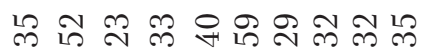

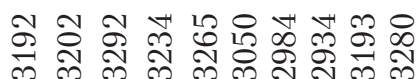

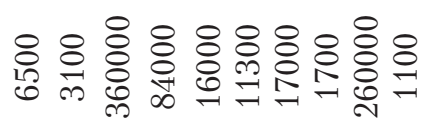

๓ ఛִ ๆ

अं

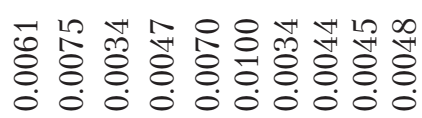

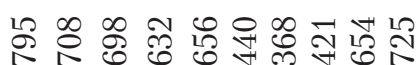

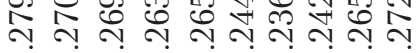

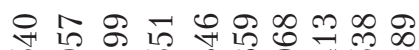

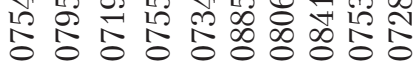

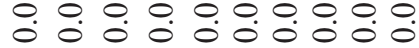

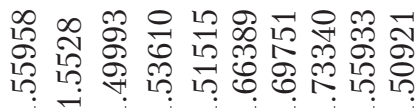

ลิ กิ

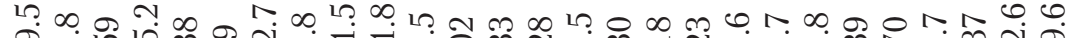

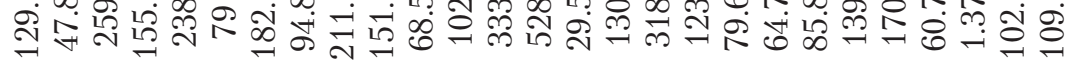

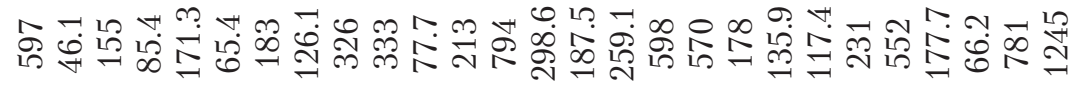

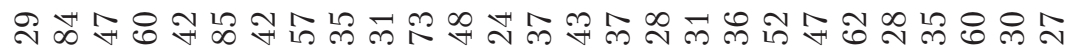

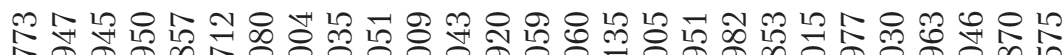

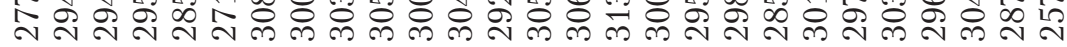

๖ำ

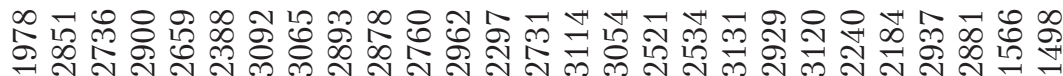
$m$
$m$
0
0
0
है
ñ

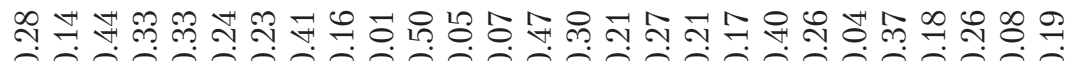

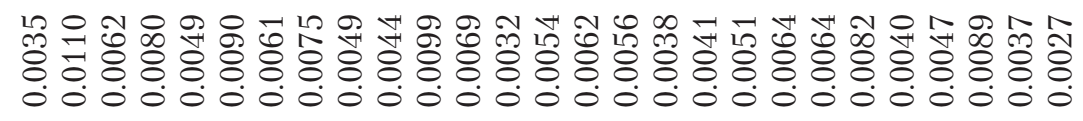

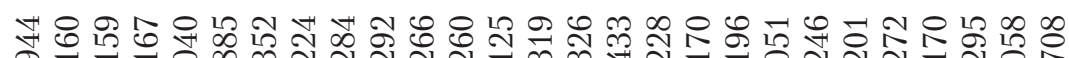

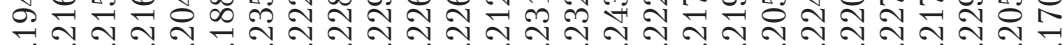
অํ

o

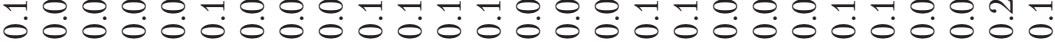

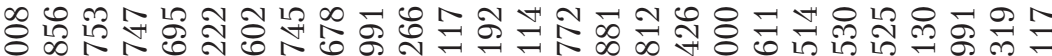

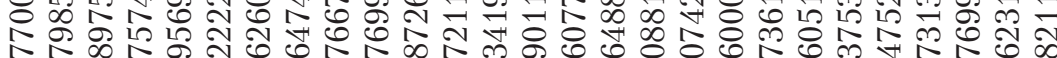
ข

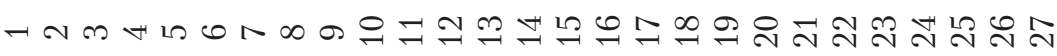




\begin{tabular}{|c|c|c|}
\hline 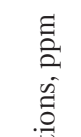 & $\hat{\sim}$ & 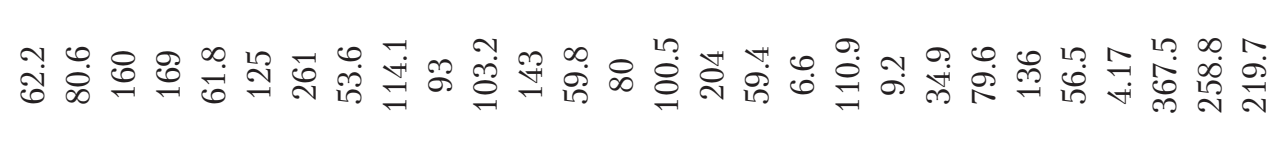 \\
\hline 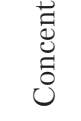 & $\supset$ & 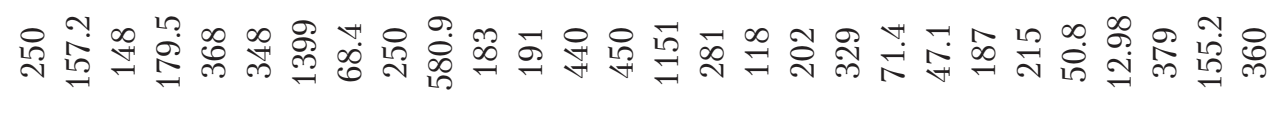 \\
\hline \multirow{4}{*}{ 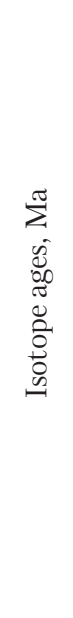 } & $\stackrel{0}{\sim}$ & 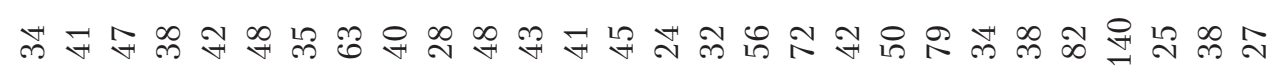 \\
\hline & 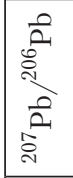 & 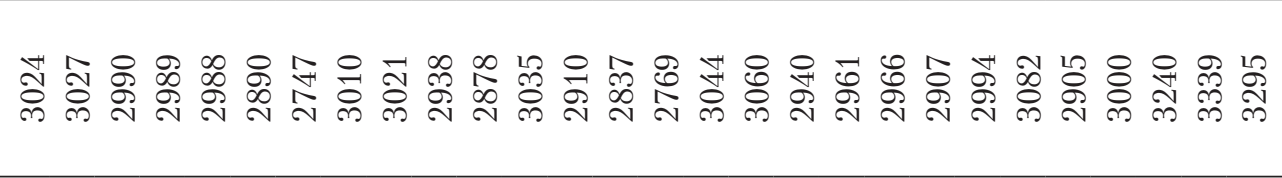 \\
\hline & $\stackrel{\circ}{\sim}$ & 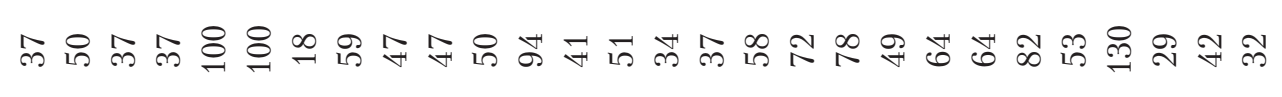 \\
\hline & 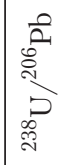 & 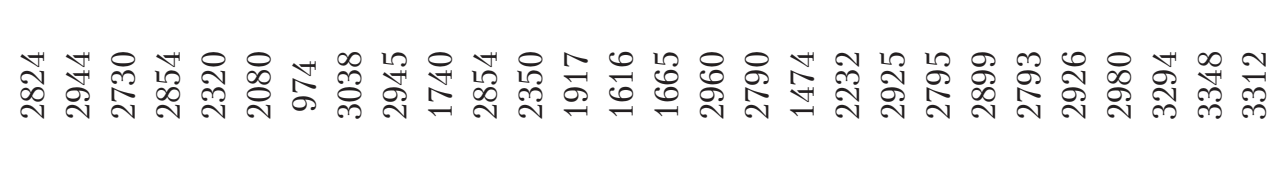 \\
\hline \multirow{6}{*}{ 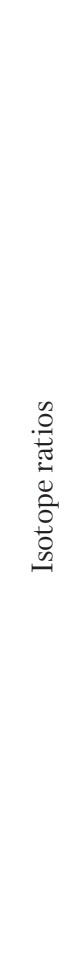 } & 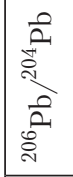 & ò \& \\
\hline & 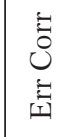 & 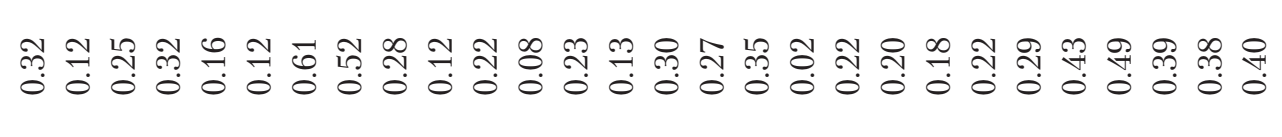 \\
\hline & $\stackrel{b}{\sim}$ & 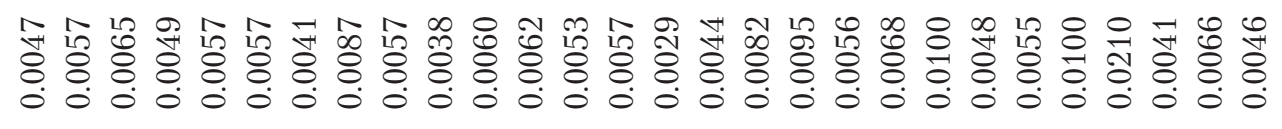 \\
\hline & 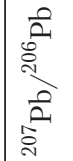 & 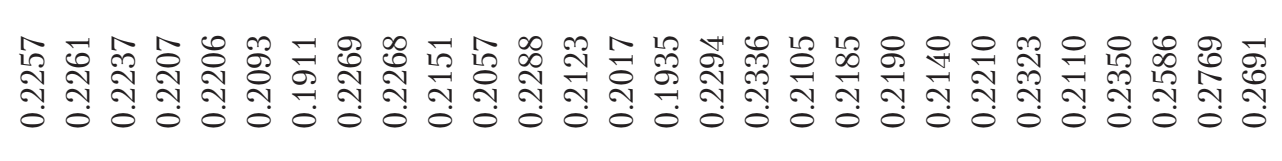 \\
\hline & $\stackrel{\bullet}{\sim}$ & 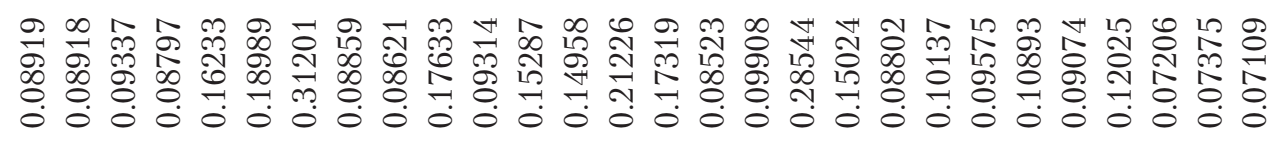 \\
\hline & 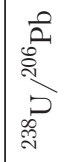 & 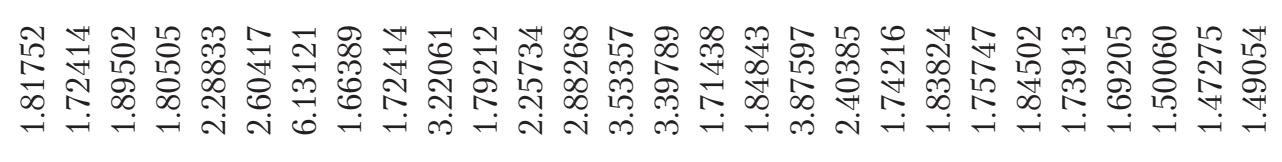 \\
\hline$\frac{\frac{m}{5}}{\frac{3}{2}}$ & & 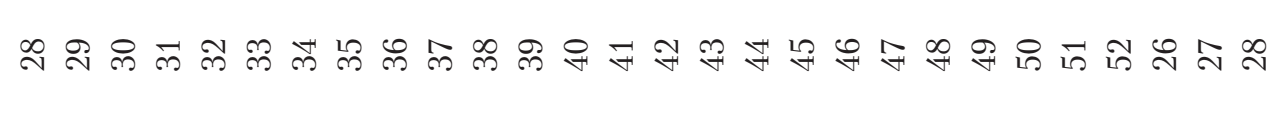 \\
\hline
\end{tabular}


net-pyroxene-magnetite rocks) of the unknown age. In terms of the chemical composition, twopyroxene schists correspond to tholeiitic basalts and basaltic komatiites, whereas ferruginous-siliceous rocks correspond to the Algoma type which is typical of the Archean greenstone belts.

The Mesoarchean (ca. $3.0 \mathrm{Ga}$ ) age of trondhjemites of the Ivanivka area of the Saltycha anticline was determined. In terms of geochemical characteristics, they correspond to the TTGs [12]. They are strongly depleted in HFSE: Y (1.3 ppm), Nb (0.64 ppm), Yb (0.52 ppm). Rare earth elements are highly differentiated $-(\mathrm{La} / \mathrm{Yb})_{\mathrm{N}}=49.2$. These trondhjemites are of the same age as TTGs of the Shevchenko complex that cut through the sedimentary-volcanogenic rocks of the greenstone structures in the Azov block. These trondhjemites could have been formed due to the partial melting at depths $>40 \mathrm{~km}$ of metabasic rocks with a restite bearing garnet and/or hornblende.

A similar age was obtained for biotite and amphibole-biotite gneisses of the "Kainkulak beds" in the area of the Zrazkove village located on the Mokra Konka river (3.1-3.0 Ga) [5] and for biotite gneisses in the lower reaches of the Kainkulak river (2.92 Ga) [14]. Correspondingly, rocks of the "Kainkulak beds" represent TTGs of the Shevchenko complex transformed into gneisses in the Paleoproterozoic due to the dislocation metamorphism.

The Late Paleoarchean (ca. 3.3 Ga) TTGs occur in the West Azov and the Kursk Magnetic Anomaly block of the Voronezh crystalline massif [15]. They can also be present in the basement of the Middle Dnieper Domain, where detrital zircons of this age occur in the Vysokopillya greenstone structure [16]. These data indicate that the extensive late Paleoarchean (ca. $3.3 \mathrm{Ga}$ ) protocraton existed in the eastern part of the Ukrainian Shield and the Kursk magnetic anomaly block of the Voronezh massif. Greenstone belts and TTGs were formed on this protocraton in the Mesoarchean (ca. 3.2-3.0 Ga) time.

\section{REFERENCES}

1. Yesipchuk, K. Yu., Bobrov, O. B., Stepanyuk, L. M. et. al. (2004). Correlative chronostratigraphic chart of the Early Precambrian of the Ukrainian shield (chart and explanatory note). Kyiv: UkrDGRI (in Russian).

2. Borodinya, B. V. (1998). Geological map and map of the minerals of the crystalline basement - 1: 200000, Central-Ukrainian Series. L-37-YII (Berdyansk). Kyiv: State Geological Survey of Ukraine, Ministry of Ecology and Nature resources of Ukraine (in Russian).

3. Razdorozhny, V. F., Vasilchenko, V. V. \& Borodynya, B. V. (2000). Stratigraphy of the Precambrian Berdyansk sheet (the South-Western Azov). Coll. articles of the meeting "Geology and magmatism of the Precambrian of the Ukrainian Shield". Kyiv, pp. 97-101 (in Russian).

4. Kravchenko, G. L. \& Dovgan, R. N. (1962). Materials for the state geological map of the USSR, scale 1: 200000, map sheets: L-37-VII and L-37-VIII. UTGF (in Russian).

5. Bibikova, E. V., Lobach-Zhuchenko, S. B., Artemenko, G. V., Claesson, S., Kovalenko, A. V. \& Krylov, I. N. (2008). Late Archean magmatic complexes of the Azov terrane, Ukrainian Shield: Geological setting, isotopic age, and sources of material. Petrology, 16, pp. 211-231 (in Russian).

6. Stern, R. A., Bodorkos, S., Kamo, S. L., Hickman, A. H. \& Corfu, F. (2009). Measurement of SIMS instrumental mass fractionation of $\mathrm{Pb}$ isotopes during zircon dating. Geostand. Geoanal. Res., 33, pp. 145-168. https://doi.org/10.1111/j.1751-908X.2009.00023.x

7. Jackson, S. E., Pearson, N. J., Griffin, W. L. \& Belousova, E. A. (2004). The application of laser ablation-inductively coupled plasma-mass spectrometry to in situ U-Pb zircon geochronology. Chem. Geol. 211, pp. 47-69. https://doi.org/10.1016/j.chemgeo.2004.06.017

8. Sláma, J., Košler, J., Condon, D. J., Crowley, J. L., Gerdes, A., Hanchar, J. M., Horstwood, M. S., Morris, G. A., Nasdala, L., Norberg, N., Schaltegger, U., Schoene, B., Tubrett, M. N. \& Whitehouse, M. J. (2008). Plešovice zircon - a new natural reference material for U-Pb and Hf isotopic microanalysis. Chem. Geol. 249, pp. 1-35. https://doi.org/10.1016/j.chemgeo.2007.11.005 
9. Paton, C., Hellstrom, J., Paul, B., Woodhead, J. \& Hergt, J. (2011). Iolite: freeware for the visualisation and processing of mass spectrometric data. J. Anal. At. Spectrom., 26, pp. 2508-2518.

https://doi.org/10.1039/C1JA10172B

10. Sun S. S. \& McDonough, W. F. (1989). Chemical and isotopic systematics of oceanic basalts: implications for mantle composition and processes. In Saunders, A. D. \& Norry, M. J. (Eds.) Magmatism in the Ocean Basins (pp. 313-345). Geological Society, London, Special Publication, Vol. 42. https://doi.org/10.1144/GSL.SP.1989.042.01.19

11. Bogatikova, O. A., Bogdanova, S. V., Borsuk, A. M. et al. (Eds.). (1987). Igneous rocks. Acid and intermediate rocks . Moscow: Nauka, Vol. 4 (in Russian).

12. Moyen, J. F. \& Martin, H. (2012). Forty years of TTG research. Lithos, 148, pp. 312-336. https://doi.org/ 10.1016/j.lithos.2012.06.010

13. Artemenko, G. V., Shumlyanskyy, L. V. \& Shvaika, I. A. (2014). Late Paleoarchean tonalite gneisses of the Western Azov block (Azov Domain of the Ukrainian shield). Geol. J., No. 4, pp. 91-102 (in Russian).

14. Artemenko, G. V., Bibikova, E. V., Samborskaya, I. A., Demedyuk, V. V. \& Shvaika, I. A. (2013). Age, geochemical features and stages of metamorphism of rocks of the Western Azov series (Azov block). Mineral. J. (Ukraine), 35, No. 4, pp. 73-85 (in Russian).

15. Savko, K. A., Samsonov, A. V., Larionov, A. N., Chervyakovskaya, M. V., Korish, E. K., Larionova, Y. O., Bazikov, N. S. \& Tsybulyaev, S. V. (2021). A buried Paleoarchean core of the Eastern Sarmatia, Kursk block: $\mathrm{U}-\mathrm{Pb}, \mathrm{Lu}-\mathrm{Hf}$ and Sm-Nd isotope mapping and paleotectonic application. Precambr. Res., 353, 106021, pp. 1-24. https://doi.org/10.1016/j.precamres.2020.106021

16. Artemenko, G. V., Shumlyanskyy, L. V. \& Wilde, S. A. (2020). The Neoarchean age of metaterrigenous rocks of the Vysokopillya greenstone structure, Middle-Dnieper Craton of the Ukrainian Shield. Geol. J., No. 2, pp. 3-17 (in Russian).

Received 28.05.2021

Г.В.Артеменко ${ }^{1}$, https://orcid.org/0000-0002-4528-6853

Л.В. Шумлянський ${ }^{1,2}$, https://orcid.org/0000-0002-6775-4419

${ }^{1}$ M.P. Semenenko Institute of Geochemistry, Mineralogy and Ore Formation of the NAS of Ukraine, Kyiv

${ }^{2}$ Curtin University, School of Earth and Planetary Sciences, Perth, Australia

E-mail: regulgeo@gmail.com, leonid.shumlyanskyy@curtin.edu.au

\section{ПАЛЕОАРХЕЙСЬКІ ТА МЕЗОАРХЕЙСЬКІ ТТГ} ЗАХІДНОГО ПРИАЗОВ’Я (УКРАЇНСЬКИЙ ЩИТ)

У Західній частині Приазовського блока знаходиться велика антиклінорна структура, яка складена породами мезоархейської (3,2-3,0 млрд років) граніт-зеленокам'яної асоціації. Вона розділена Білоцерківською структурою субширотного простягання на дві частини - північну, що включає Гуляйпільський і Ремівський блоки, і південну - Салтичанський антиклінорій. Визначено, що U-Pb вік плагіогнейсів Ланцівської антикліналі Білоцерківської структури становить $3299 \pm 11$ млн років. За геохімічними характеристиками біотитові гнейси відповідають ТТГ. На відстані 30 км у західній частині Білоцерківської структури раніше нами були виявлені кварцеві діорити такого ж віку $-3297 \pm 22$ млн років. Ці дані показують, що Білоцерківська структура є блоком давнього фундаменту. На Іванівській ділянці східної частини Салтичанського антиклінорію вивчені дислоковані тронд’єміти. Визначено, що U-Pb вік тронд’ємітів $3013 \pm 15$ млн років. Ці тронд’єміти, таким чином, є одновіковими з ТТГ шевченківського комплексу, які проривають осадово-вулканогенні породи зеленокам'яних структур Приазовського мегаблока. Пізньопалеоархейські (3,3 млрд років) тоналіти, поширені на Західному Приазов”і, знайдено також на мегаблоці КМА Воронезького кристалічного масиву, і, ймовірно, вони є у складі гнейсового фундаменту Середньопридніпровського блока, де у Високопільській зеленокам'яній структурі було знайдено кластогенний циркон такого віку. Ці дані вказують на вірогідне існування більш давнього протократону віком 3,3 млрд років, на якому формувалися мезоархейські (3,2-3,0 млрд років) зеленокам'яні пояси східної частини УЩ і мегаблока КМА.

Ключові слова: Західне Приазов'я, Білочерківська структура, Салтичанський антиклінорій, палеоархейський прократон, мезоархейський кратон, ТTГ, Український щит, ииркон, $U$-Pb вік. 